\title{
Implementation of Certified Energy Management System in Municipality. Case Study
}

\author{
Anda JEKABSONE ${ }^{1 *}$, Agris KAMENDERS ${ }^{2}$, Marika ROSA ${ }^{3}$ \\ ${ }^{1-3}$ Institute of Energy Systems and Environment, Riga Technical University, Azenes iela 12/1, \\ Riga, LV-1048, Latvia
}

\begin{abstract}
The European Union has taken the course to become climate neutral by 2050 . To reach that target significant changes in all sectors are necessary, resulting in increasing regulatory pressure on energy producers, consumers and other sectors. Increasing legal requirements was also one of the reasons why the city of Daugavpils (population of 82 000) took a decision to implement an Energy management system (EnMS). In the boundaries of EnMS Daugavpils included more than 100 public buildings, public transportation and public lighting. This research paper presents results of the EnMS implementation, main drivers and barriers that Daugavpils has faced and overcome in the implementation process, and also assesses the benefits the city of Daugavpils has gained from EnMS. The success rate of EnMS in such an organisation as a municipality is based on the awareness and knowledge of the municipality's employees and support from the municipality leaders. The case study of Daugavpils shows energy savings of $12 \%$ in the public building sector after implementing EnMS.
\end{abstract}

Keywords - Energy efficiency; energy management; energy management systems; energy planning; ISO 50001; sustainable energy action plans

\section{INTRODUCTION}

In the last decade, environmental and climate issues have significantly affected the decision-making process for policy makers, market and industry professionals. Many different policy instruments have been created to address climate issues, for example regulatory and economic tools carried out by governments, like laws, taxes, emission trading systems, and voluntary agreements, like certification schemes, labels, etc. [1], [2] One of the most applied tools for reducing environmental impact is the Environmental Management system (EMS) [3], [4]. While there can be many different EMS, even individually designed ones, the most widely known are ISO 14001 and European Union's EMAS (Eco management and auditing scheme). Implementation of these schemes helps organizations to be compliant with the growing regulatory requirements and to communicate environmental performance with the public [5]. Following the success of the Environmental management system, ISO 50001 Energy management system (EnMS) was launched in 2011. The aim of the standard is to enable organizations to establish the systems and processes necessary to continually improve energy performance, including energy efficiency, energy use and energy consumption [6]. EnMS helps energy efficiency measures become a part of daily processes, rather than individual energy efficiency projects [7].

\footnotetext{
${ }^{*}$ Corresponding author.

E-mail address: anda.jekabsone@edu.rtu.lv 
Backlund et al. has concluded that by improving energy management practices, it is possible to save up to $20 \%$ of energy and that energy efficiency measures without proper energy management practices do not ensure the best results [8], [9]. Pelser et al. have found that it is possible to reduce electricity consumption at a cement plant by $25 \%$ using the ISO 50001 approach and without additional investments in equipment [10]. Some countries have already introduced legislative requirements to introduce ISO 50001 in large industries [11]. Bottcher and Müller has studied the German automotive industries and found that implementation of ISO 50001 does contribute to better carbon performance, which is associated with better economic performance of the company. They also argue that the advantages of ISO 50001 compared to ISO 14001 are that the former is narrower and more focused on specific targets, and thus more comparable and measurable. Another advantage is that it requires more involvement of top management [12]. Phan and Baird has highlighted that there is variation in the extent of use of EMS across different industries, however all have been granted the same certificate [13]. Other authors also highlight that some organisations use ISO 14001 more as a marketing tool, while real environmental performance is mostly symbolic [14], [15].

ISO 50001 is applicable to any type of organization, from huge industrial enterprises to small organizations, and it is compatible with ISO 14001 and ISO 9001 due to its similar structure. It has international recognition; therefore, it is widely used [16]. Also ISO-maintained data shows that the number of issued certificates in Europe has increased significantly, from 5526 certificates in 2014 to 17655 certified systems in 2017 [17]. Research shows that in countries with the highest number of certifications, the main reasons to adopt ISO 50001 are the presence of legislative norms to reduce GHG emissions and prior adoption of ISO 9001 and ISO 14001. If an organisation has already introduced any other ISO standard, it is easier to introduce new ones [18].

One of the approaches that has been used in many public and private buildings is the "Building Energy Management System" (BEMS) [19]-[23]. In most cases, BEMS includes smart systems, and analysis of energy use in buildings in relatively high detail and it is mostly used in huge buildings or building complexes. It can, however, become a heavy approach when applied to a large number of buildings, which can be widely spread across a bigger territory as in the case of municipalities. When a municipality has to manage energy in more than 100 buildings, as well as street lighting and transport, a more holistic and universal approach has to be used, to control the system centrally.

In recent years, municipalities have started to apply ISO 50001 methodology to their energy planning, showing promising results, that implementation of ISO 50001 in municipalities might foster energy savings faster [24], [25]. Data show that payback time of the implementation of EnMS in a municipality can be even less than a year [26].

Currently, approximately 20 municipalities in Europe have received an ISO 50001 certificate (no precise statistics are available, therefore the assumption is based on measures taken by EU funded projects, like "Energy for Mayors", "compete4SECAP", "5000\&1 SEAP"). One of the main drivers to introduce EnMS in municipalities is a growing national pressure to achieve GHG and energy efficiency targets. In Latvia, for example, one of the problems identified is predominant reliance on the availability of EU funding, which contributes to negative fluctuations of costs (when external funding is available costs tend to increase) [27] and this issue can be addressed through sustainable planning.

Though the number of certified companies is increasing, the number of certified municipalities is still low. There are more than 9500 municipalities around Europe that have joined the Covenant of Mayors ( $\mathrm{CoM})$ initiative. Most of them have a potential to introduce 
EnMS, however there is currently very few evidences whether and why municipalities should introduce EnMS for their assets.

The aim of this paper was to research and present the current status of EnMS performance in one municipality. To do so, three research questions were identified:

1. What is the precondition for implementation of EnMS?

2. What are the main benefits from implementation of EnMS in a municipality?

3. What are the most important factors for EnMS to successfully function?

The case study was used to research these questions. The studied municipality - city of Daugavpils - is the first municipality in Europe that certified ISO 50001 with the broadest boundaries. Analysis is limited to data gathered by municipality within EnMS since 2016 and historical data since 2014. An individual interview with the energy manager of Daugavpils city was carried out to understand the procedural practices. Daugavpils has a population of approximately 82000 . The results are not applicable to very large or very small cities. The choice of research methods is explained in the Methodology section.

\section{Methodology}

\subsection{Background}

Many European municipalities, including all CoM signatories, use Sustainable energy and climate action plans (SECAP) as a tool for addressing climate change and energy targets. CoM reports show that in many cases SECAP implementation has resulted in significant reduction of $\mathrm{CO}_{2}$ emissions and energy consumption [28], [29]. But as Petersen argues, while leading municipalities show good results, less active municipalities struggle with meeting the energy and emission targets set in SECAP [30]. Therefore, effectiveness of SECAP methodology can be argued.

As energy planning for most of municipalities in Latvia is not mandatory, there is no defined framework of sustainable energy planning. Nevertheless, it is expected that municipalities act on increasing the share of renewable energy and reducing energy consumption. Research shows that in Latvia there is great potential for developing other renewable technologies, instead of biomass combined heat and power plants (CHP) [31], and great emphasis is placed on development of $4^{\text {th }}$ generation district heating systems [32], [33]. However, previous research shows that many municipalities lack the experience and knowledge to implement measures included in SECAP. Therefore, it is important to examine what instruments can motivate municipalities to implement approved SECAPs. From this perspective, EnMS according ISO 50001 is one of such instruments for municipalities with limited knowledge and experience as the standard provides clear structure and procedures for the introduction of a systematic reduction of energy consumption in public assets.

\subsection{Theoretical Framework}

The theoretical framework of this research paper is based on methodology proposed by Kamenders et al. (see Fig. 1) [26]. It was selected as the most appropriate and to the date as the only methodology to analyse the efficiency of EnMS in municipalities. This theoretical framework consists of four main phases.

The first phase is to ensure the political commitment of the municipality towards mid-term and long term local, regional, national and/or international energy and climate targets. It means that the municipality acknowledges the national goals and shows a willingness to act on them. 
The second phase is the planning phase, when the municipality analyses the current situation, and based on the results of the analysis, sets annual quantitative and qualitative targets. The current situation analysis is carried out by the municipality itself or outsourced. Initially historic data are gathered to be used as a baseline for comparison. The municipality identifies actions to be implemented in order to achieve the targets.

The third phase is implementation and operation of the EnMS, which includes implementation of identified actions and procedures, e.g. regarding monthly data collection and assessment of deviations. According to this framework, implementation includes all the principles of energy management, including data collection and monitoring.

The last phase is checking, which includes internal audits, assessment of the results and measurements to identify strengths and weaknesses of the established system. In this phase, further corrective and preventive actions are taken.

The timeline of all four phases is one year. Based on the results from the checking phase, the municipality revises its commitment and sets new annual targets. This ensures that the overall energy management system is adaptive to new realities and necessities, and this adaptation process can be based on reliable data.

In this research paper, the theoretical framework is applied to analyse the case study of Daugavpils (see Section 3.3).

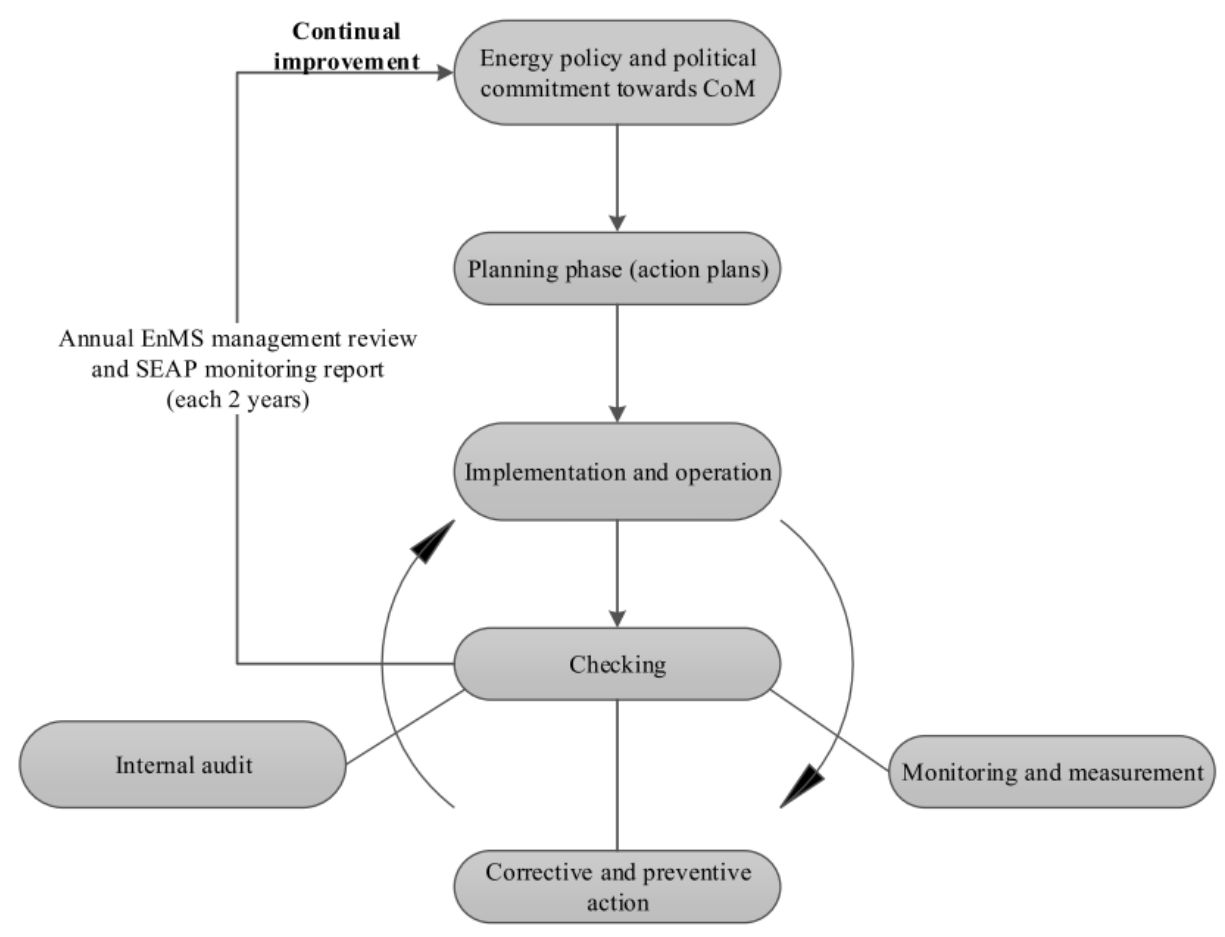

Fig 1. Methodology of the integrated EnMS and SECAP approach [26]. 


\subsection{Background of the Municipality}

The city of Daugavpils is the second largest city in Latvia with a population of 82604 (at the beginning of 2019) [34]. It is located in the southeast of Latvia, close to borders with Lithuania and Belorussia. The municipality employs around 5910 persons. In 2015, the total heat consumption in public buildings was $\sim 47.7 \mathrm{GWh}$; average specific heat consumption $185 \mathrm{kWh} / \mathrm{m}^{2}$ a year. Total electricity consumption in public buildings was $17.1 \mathrm{GWh}$, electricity for street lighting was $\sim 5.6 \mathrm{GWh}$. Energy consumption for public transport was $\sim 13 \mathrm{GWh}$ (buses, minibuses, trams) [35].

In 2016, Daugavpils signed the Covenant of Mayors and has participated in the 2017 CEM Energy Management Leadership award and received the Energy Management Insight Award for helping to build awareness of ISO 50001 and for contributing to global knowledge of energy management implementation.

\subsection{Quantitative Data Collection}

This study used multiple data collection and analysis methods, like desk research, policy document analysis, quantitative data analysis and a questionnaire. Two main policy documents were analysed "Daugavpils Sustainable Energy Action plan until 2016-2020" and "Energy management system manual for the city of Daugavpils", as well as annual ISO audit reports. Additionally, the questionnaire was used in a previous publication by Jekabsone et al. [36]. The questionnaire was completed by the energy manager of the city of Daugavpils, and it provided qualitative data about the EnMS implementation process.

All the energy data used in this article were collected by municipality personnel via an energy monitoring platform introduced in the municipality according to EnMS procedures. The municipality issued an order for technical personnel in the public buildings to ensure monthly energy data entry into the energy monitoring platform.

Technical personnel submit heat, electricity and hot water consumption data. The energy manager submits data on monthly energy tariffs and average outdoor air temperature. Heat energy consumption data are climate-corrected using a national methodology, which is based on ISO 13790:2008 that gives calculation methods for assessment of the annual energy use for space heating and cooling of a residential or non-residential building [37], [38]. Data analysis and visualization is available in the platform according to ISO 50001 requirements and local legislation. In case of each building, the platform calculates and reports monthly deviation in energy consumption.

In this research paper, only EnMS in public buildings were studied.

Data of the five-year period (2015-2019) has been analysed to understand the quantitative results of measures taken by the municipality. Daugavpils municipality has included almost all the municipal infrastructure in the EnMS, which makes their system the largest certified EnMS in Latvia. EnMS covers a significant part of sectors included in SECAP.

Currently the municipality has a database of energy consumption data since 2012.

Data of 2012-2015 were gathered during the first planning phase as historic data. Since 2016, the municipality started collection of actual monthly data through the online energy management platform. Additional information about buildings was requested from the energy manager of Daugavpils.

\subsection{Analytical Framework}

Based on the theoretical framework, assessment of the EnMS was performed in four phases through evaluation of the following aspects: 
Phase 1: motivation of the city to develop EnMS (and SECAP);

Phase 2: setting EnMS (and SECAP) boundaries and targets;

Phase 3: introducing and organising EnMS implementation process;

Phase 4: assessing the monitoring and implementation process, including communication between departments and other stakeholders during implementation.

Within phase 1 , the challenges the municipality faced regarding energy efficiency are explained, while in phase 2 the chosen targets and boundaries are analysed. In phase 3 the main steps for implementing the EnMS are explained. Phase 4 shows how the energy data were exchanged and organized before and after the implementation of the EnMS.

\section{Analysis AND Results}

During 2015 and 2016, the city of Daugavpils worked in parallel on the development of both the SECAP and EnMS. The EnMS manual defines procedures for implementation, operation and monitoring of the EnMS, while SECAP defines strategic climate mitigation targets and actions in all the territory of the municipality. Both documents were approved by the city council in 2016 . At the end of 2016, the city of Daugavpils received the ISO 50001:2012 certificate.

The estimated total budget for implementation of SECAP was 61 million EUR, from which $67 \%$ was planned from EU funding, $19 \%$ from the budgets of municipal enterprises, $9 \%$ from the municipal budget, $5 \%$ national government funding.

The share of the overall municipal budget dedicated to the public sector is $51-75 \%$.

\subsection{Phase 1: Motivation of the City to Develop EnMS (and SECAP)}

Between 2010 and 2014 multiple public building renovation projects were implemented in Daugavpils, mainly in education facilities. Upon completion, almost none of the projects met the expected energy consumption. This was one of the issues that led to the conclusion that energy efficiency should be addressed more diligently. Afterwards other challenges were identified, like:

- Lack of energy consumption data and its analysis;

- No responsibilities assigned to energy management, no energy manager;

- Selection of energy efficiency measures were "project-based" lacking a systematic approach and there was no methodology on how to select the buildings for renovation;

- Data collection was chaotic and with low transparency (hard to track down energy data and costs).

All these observations led to the conclusion, that energy management would lead to better decision-making and would save financial resources.

The municipality started the development of EnMS in late 2015 and early 2016. The whole process took about one year and the timeline of the main steps of the process is illustrated in Fig. 2. The city of Daugavpils received important support and training from external experts.

After the city initiated introduction of the EnMS in its assets, a new Energy Efficiency Law was approved in Latvia in 2016. The Law was based on the EU Energy Efficiency Directive [39] and introduced a new mandatory norm for the nine largest cities in Latvia (including the city of Daugavpils) to implement and certify EnMS. This was an important factor that accelerated the process. 


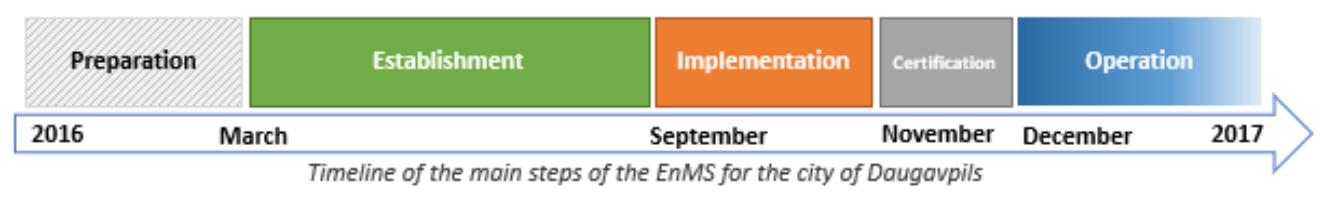

Fig. 2. Main steps of the EnMS implementation process [40].

\subsection{Phase 2: Setting EnMS (and SECAP) Boundaries and Targets}

The city of Daugavpils was working in parallel on its EnMS and SECAP. The main focus areas of SECAP are centralised heat energy production, energy savings in buildings, energy savings of street lighting and public transport. Energy performance of the private sector is included briefly in the form of informative measures, without strong commitments to gain results.

Initially the boundaries of the EnMS included 100 public buildings, public street lighting system with 9183 luminaires and total length of the system of $351 \mathrm{~km}$ as well as public transport with over 90 vehicles for 32 bus and 3 tram routes. In 2018 the boundaries were extended and now includes an additional 25 public buildings.

The share of each sector before EnMS implementation in 2015 is shown in Fig. 3. The largest sector is heating in public buildings (49\% of all energy consumption), $11 \%$ is electricity consumption in buildings, $28 \%$ is public transport, and only $10 \%$ is public lighting [41].

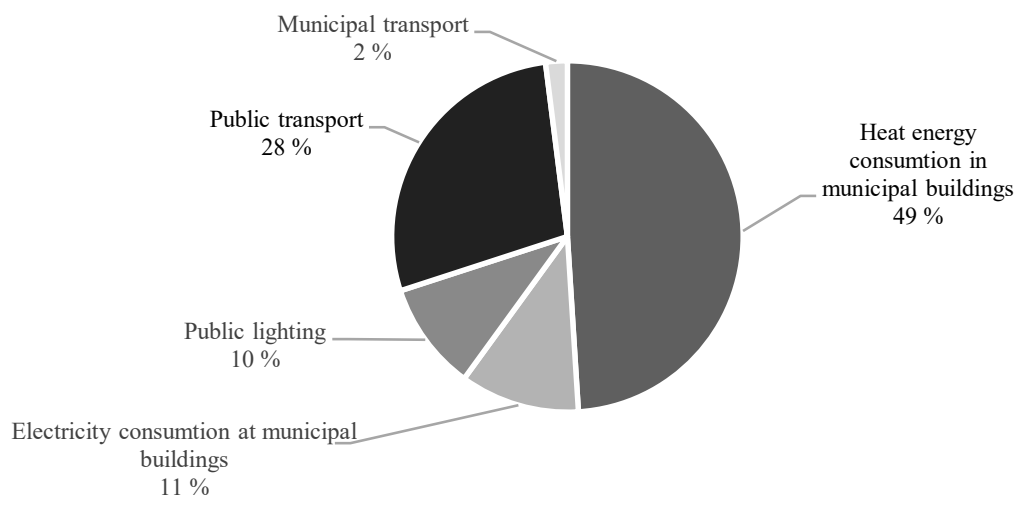

Fig. 3. Distribution of municipal energy consumption in Daugavpils in 2015.

If SECAP sets mid- and long-term targets, targets in EnMS are defined by the municipality annually. SECAP of Daugavpils sets a strategic goal to reduce $\mathrm{CO}_{2}$ emissions by $40 \%$ until 2030 in the whole territory of the city. EnMS was chosen as one of the tools to move towards this target.

In the meantime, the targets of EnMS in the first year (2016) were considerably grounded, i.e. to implement and certify the system, to identify 10 public buildings with the highest specific heat consumption, and to analyse the patterns and behaviours of the energy users in these buildings. Additionally, targets were also set for street lighting and the public transport sector. As only partial historical data were available for these sectors, the objective was to ensure monthly data collection. Quantitative targets related to the reduction of energy consumption were set starting from 2017. 
Even though implementation of the EnMS in Daugavpils at that stage was a mandatory requirement, municipalities were free to set the boundaries of EnMS. In contrast to other cities, the city of Daugavpils decided to have large boundaries, including public buildings, street lighting and public transport.

\subsection{Phase 3: Introduction and Organisation of the EnMS Implementation Process}

The planning and implementation process of EnMS consists mainly of three steps development of manual and procedures, issuing orders of responsibilities and organizing training for involved employees. The ISO 50001 standard itself doesn't require to develop a manual of the system, but as municipalities often have a high rotation of employees, this step is essential for maintaining the system without losing overall knowledge. After the manual and procedures were set, official orders were issued to technical personnel, defining how to collect and submit data. After this process, multiple trainings were organised for employees involved in the system, to motivate them by giving the understanding of the whole system and its targets.

\subsection{Phase 4: Assessing Monitoring and Implementation Process, including Communication between Departments and Other Stakeholders during Implementation}

Before the EnMS was implemented in Daugavpils, heat and electricity consumption data were gathered only at the building level. The appointed person of each building sent the readings of the energy meters to the energy supplier on a monthly basis. Based on the bill from the energy supplier, each building paid the bill. The annual energy budget of each building was ensured by the municipality and was based on the average costs in the previous year. Energy costs were not analysed separately from other costs in the building. At that time nobody in the building was informed about energy consumption on a regular basis, and in most of the cases data were not compiled even annually. The flow of energy data and financial resources in 2015 are shown in Fig. 4.

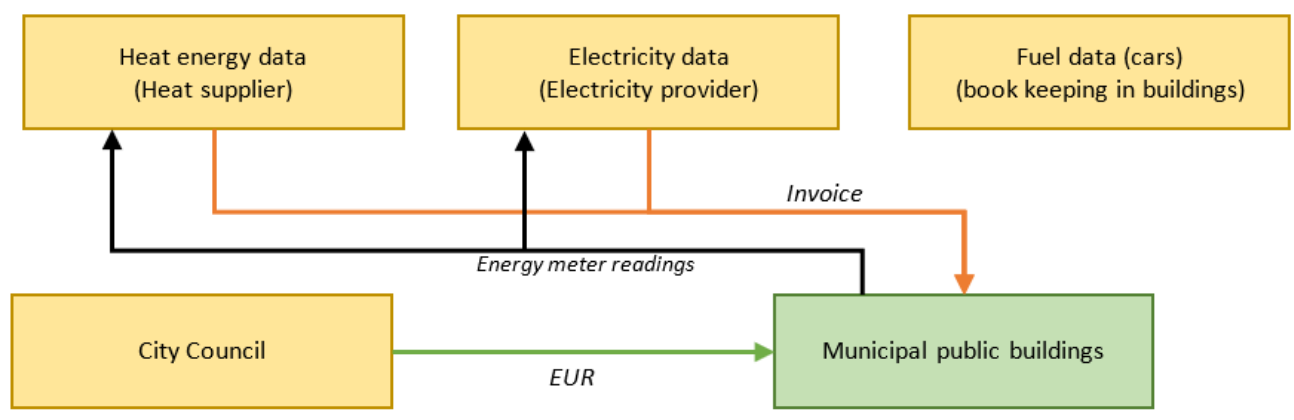

Fig. 4. Energy consumption data management system in Daugavpils municipal buildings before EnMS.

After the EnMS was introduced, new data information flow was introduced so the information would be gathered centrally, and analysed on a regular basis (see Fig. 5). Based on the results, feedback to buildings should be provided and reports to SECAP working group delivered to feed the decision making. 


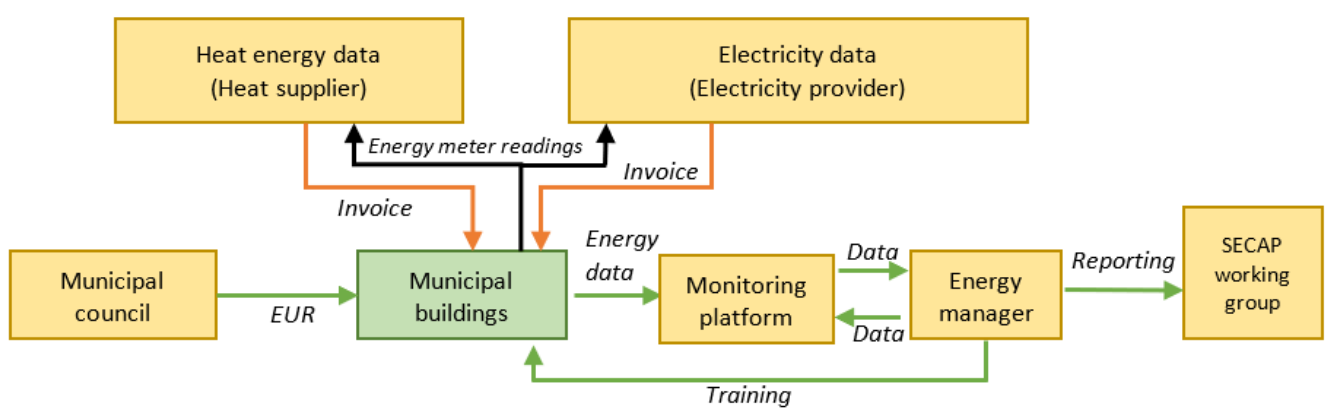

Fig. 5. Energy consumption data management system in Daugavpils municipal buildings after EnMS.

The administrative body that is responsible for SECAP and EnMS implementation is the Department of Development of the Daugavpils City Council. Approximately 218 persons are involved in EnMS to some extent, all the personnel costs are funded by the municipality. External experts are involved only for specific tasks where municipal personnel are not qualified, like, energy audit and ISO certification audit. Daugavpils also started to employ an energy manager the person responsible for EnMS monitoring, maintenance, analysis of results and annual reports. The necessity of an energy manager was already identified by Dzene et al. in an article about the implementation of a centralized monitoring and energy management system [24].

Historical data were gathered during the development of SECAP, but within EnMS, Daugavpils started the systematic and continuous collection of monthly data. Daugavpils chose to use the Online Energy Monitoring Platform, a tool for data collection and analysis. Municipal employees have to insert data regularly, and the tool automatically calculates the deviations and analyses data tendencies. The energy manager then checks the data every month and acts on deviations, according to procedures. As other authors have discovered, the maintenance of monitoring is often the most complicated part of EnMS [42], [43], therefore a ready to use tool for calculations can play a significant role in success of EnMS.

The data of municipal buildings is gathered for each building separately where possible, if not aggregated data for multiple buildings are collected. Data that is collected is heat and electricity consumption, and it is done mostly by manual readings of energy meters. Monthly average temperatures and average tariffs are submitted by the energy manager. Municipality have indicated that the main obstacles concerning the collection of energy relevant data have been mistakes by personnel - faulty data readings, missing data because employee forgot to read the meter or was on sick leave, and no other person was assigned to the task. After facing these obstacles, the municipality improved its procedures, each person received clear guidelines on how the reading should be done, on what date and who should do it, if the person directly responsible is not able to read the measurements.

Few other obstacles were identified by the energy manager after implementation of EnMS, like low motivation of personnel involved in EnMS, lack of knowledge within municipal employees about energy efficiency of buildings, public lighting and transport and low understanding of EnMS data. These issues were addressed by organizing educational workshops and seminars for employees.

Some challenges with data collection and system management were identified during the certification audit in 2019. Mainly lack of human resources caused delays in reporting and data input. It has been suggested by auditors to improve the system on how information from employees is collected about suggestions of system improvements and to update energy strategies 
and policies on a regular basis. The results of the audit also showed that employees in all buildings and departments are informed and have knowledge about energy performance of the building, as a result of the EnMS implementation.

\subsection{Analysis of Energy Data of Municipal Buildings}

The ISO 50001:2018 standard stimulates organisations to introduce a systematic approach towards the efficient and rational use of energy. To assess the results, organisations should use key performance indicators. In case of buildings, one of the key performance indicators is specific energy consumption. It is essential to differentiate specific heat consumption and electricity consumption. Moreover, when applicable, climate corrected annual heat energy consumption should be used.

As the city of Daugavpils has more than 120 buildings in their EnMS, it is not enough to use performance indicators. Additional comparative analysis shall be made to select significant energy users, i.e. priority buildings.

Fig. 6 and Fig. 7 show a method how municipal buildings can be divided in four different groups to be approached accordingly. Data from the city of Daugavpils in 2015 and 2019 are used. Boundaries of these groups can be adjusted, depending on the energy data and how many buildings the municipality needs to include.

The main idea is to find the buildings with the highest energy efficiency potential, by dividing all buildings in four groups depending on their total energy consumption and specific heat energy consumption. The borders of the groups are defined according to the targets of the municipality, respectively lines (red dashed lines in Fig. 6) are drawn as close to the lower left corner as it is needed to distinguish enough buildings.

The least number of actions are required for buildings in the $3^{\text {rd }}$ group, as they don't use much energy and are considerably efficient, which means that there is relatively small potential for energy savings. Also the $4^{\text {th }}$ group can be considered as the one which doesn't require an action, but as these are buildings with large energy consumption, even a small decrease in specific energy consumption can ensure huge savings in terms of money. The $1^{\text {st }}$ group of buildings are the ones with smaller total energy consumption, but very high specific energy consumption, which means that these buildings have a lot of potential for energy efficiency. The goal would be that all the buildings would reach the level of efficiency to be classified in the $3^{\text {rd }}$ group. The group with the highest energy efficiency potential is group 2, as these buildings have high specific and total energy consumption. Often in these buildings even small energy efficiency measures can give significant benefits. Therefore, strategically the best decision is to invest in these buildings. And, in time, the buildings should be regrouped, and the borders should be moved closer to the lower left corner of the graph, for setting new priorities.

In case of Daugavpils, 5 buildings were in the $2^{\text {nd }}$ group in 2015. One of the successful examples is building 5 - a specialized school with an area of $5844 \mathrm{~m}^{2}$, which was renovated in 2013, but did not meet the expected energy efficiency level. The municipality introduced the regulation and automatization of the heating system, and eventually this building moved from the $2^{\text {nd }}$ to $3^{\text {rd }}$ group. Consumption in this building reduced from $1273 \mathrm{MWh}$ in 2015 to $899 \mathrm{MWh}$ in 2019, respectively specific consumption reduced from $218 \mathrm{kwh} / \mathrm{m}^{2}$ year to $154 \mathrm{kwh} / \mathrm{m}^{2}$ year. Renovation has been started in the first building (care centre for the elderly) in 2019 . At the $2^{\text {nd }}, 3^{\text {rd }}$ and $4^{\text {th }}$ building, no significant actions have been taken, these buildings are the water management facility, tuberculosis hospital, and public transport station.

There were 3 buildings in the $3^{\text {rd }}$ group. Positive improvements can be seen in all of them because of small improvements that have been done. The $6^{\text {th }}$ and $7^{\text {th }}$ were renovated in 2013-2014, 
$2020 / 24$

but did not meet the target energy efficiency, but after EnMS implementation, the situation has improved.

Also 2 buildings in the $1^{\text {st }}$ group were identified, because of very high specific heat consumption. Building 9 is a public sauna, which hasn't been addressed in terms of energy efficiency. Building 10 was renovated in 2013-2014, and did not meet the energy efficiency targets.

In all 10 buildings total energy savings in 2019 have been $11 \%$, compared to 2015 .

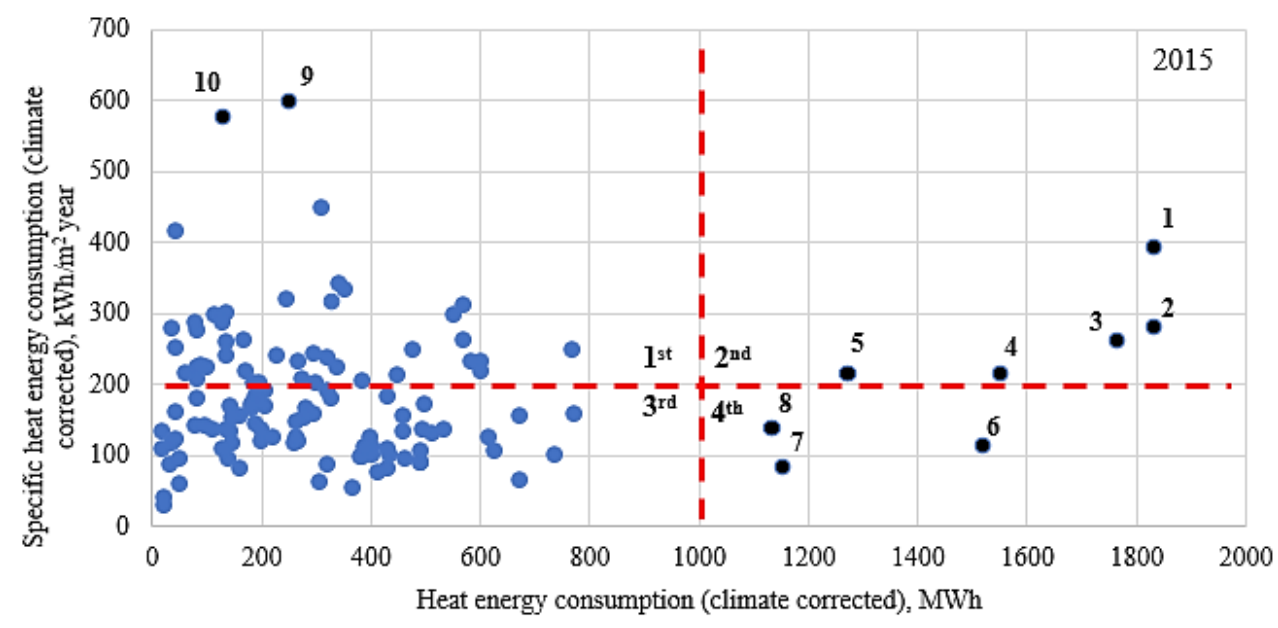

Fig. 6. Heat energy consumption at 123 municipal buildings of the city of Daugavpils in 2015 .

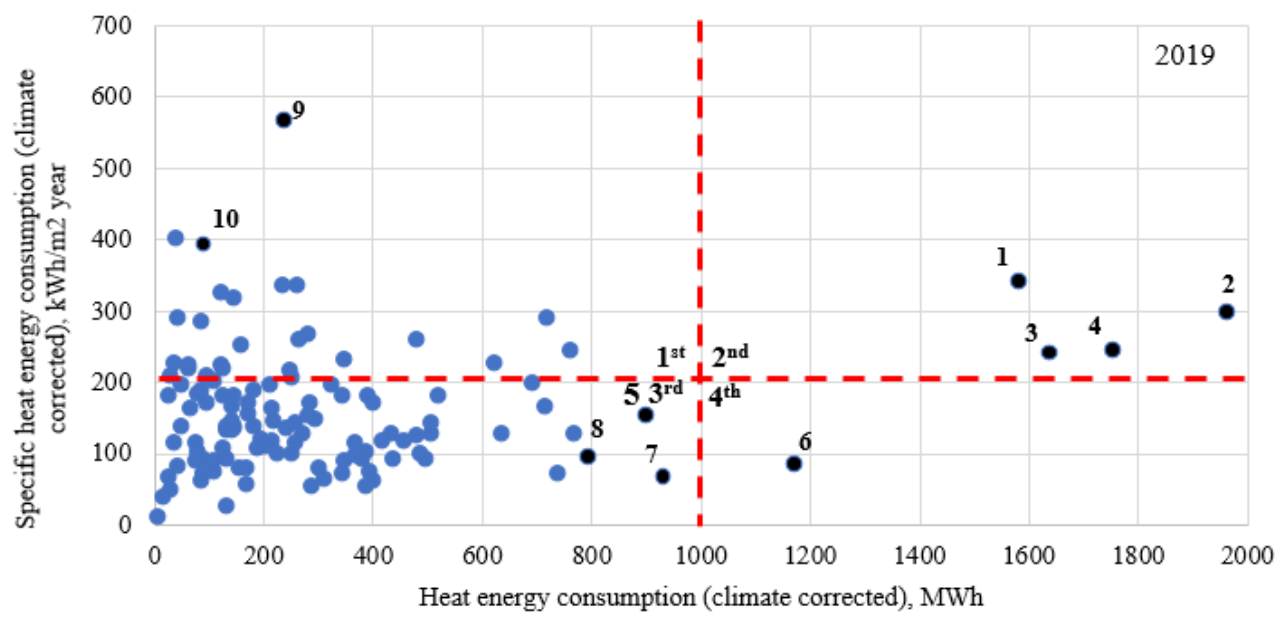

Fig. 7. Heat energy consumption at 123 municipal buildings of the city of Daugavpils in 2019.

One building - the city hospital - was excluded from the graph, because of its significantly higher energy consumption - 5240 MW in 2015 and $4288 \mathrm{MW}$ in 2019 (climate corrected). The respective specific heat energy consumptions were 137.8 and $112.8 \mathrm{kWh} / \mathrm{m}^{2}$ year. Nevertheless, 
$2020 / 24$

this building should also be addressed, as it has the biggest energy consumption in the municipality.

Since the EnMS was introduced, nine buildings (schools and kindergartens) have been renovated. Energy performance of these buildings before and after renovation is shown in Fig. 8 . Energy consumption in most of the buildings has been significantly reduced. Energy savings in 2019 in 9 renovated buildings were $47.7 \%$. However, the full potential has not yet been achieved in three buildings where specific heat energy consumption is still above $150 \mathrm{kWh} / \mathrm{m}^{2}$ year (buildings 3, 5 and 9). This indicates, that more action should be taken.

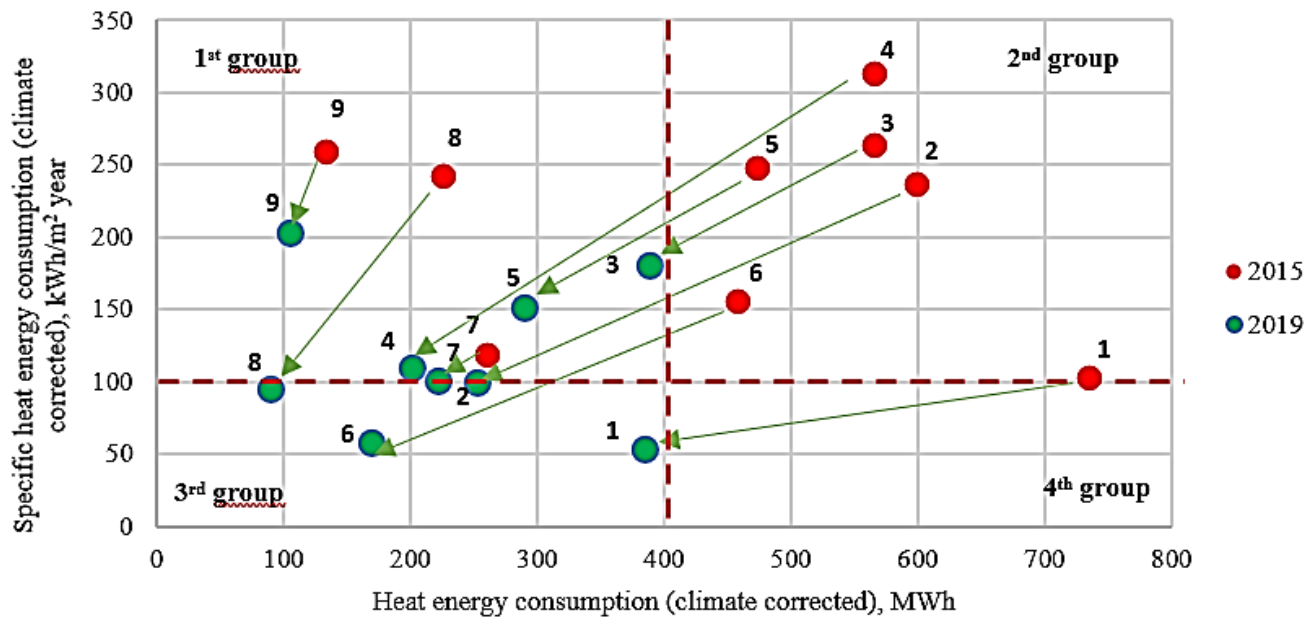

Fig. 8. Heat energy consumption at 9 municipal buildings of the city of Daugavpils which were renovated during 20162018 .

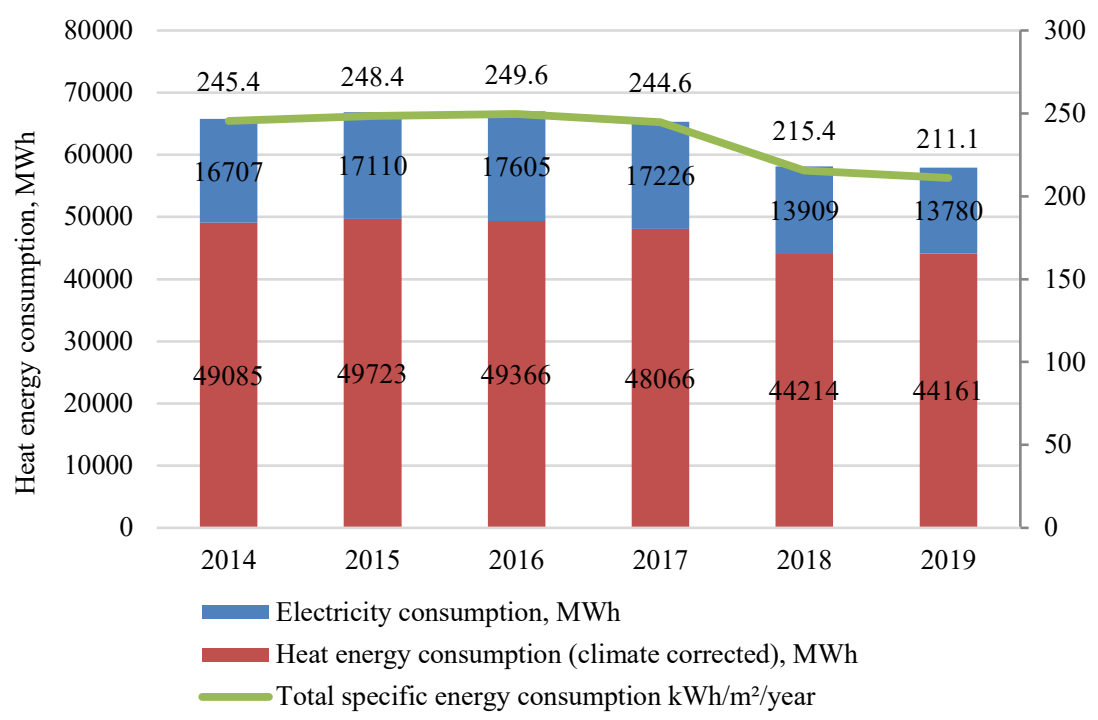

Fig. 9. Total energy consumption of 123 municipal buildings in Daugavpils (in 2014 and 2015 only partial historical data are available and energy consumption was higher). 
Since implementation of the energy management system in 2016, heat energy consumption in all 123 buildings together has been reduced by $12 \%$ or $5.2 \mathrm{GWh}$ (climate corrected data). Electricity consumption in 2019 has decreased by $8 \%$ compared to 2016.Also, only since 2016 full set of data for all buildings are available and data for 2014 and 2015 are partial, explaining the increase in energy consumptions from 2014 to 2016.

\subsection{Cost Savings and EnMS Implementation Costs}

Every year the Daugavpils municipality spends around 5.5 to 6 million EUR for energy in public buildings (heating and electricity). In 2019 due to the energy savings, costs for energy were reduced by $8 \%$ compared to 2016, when EnMS was implemented. This was achieved even though electricity costs increased during these years.

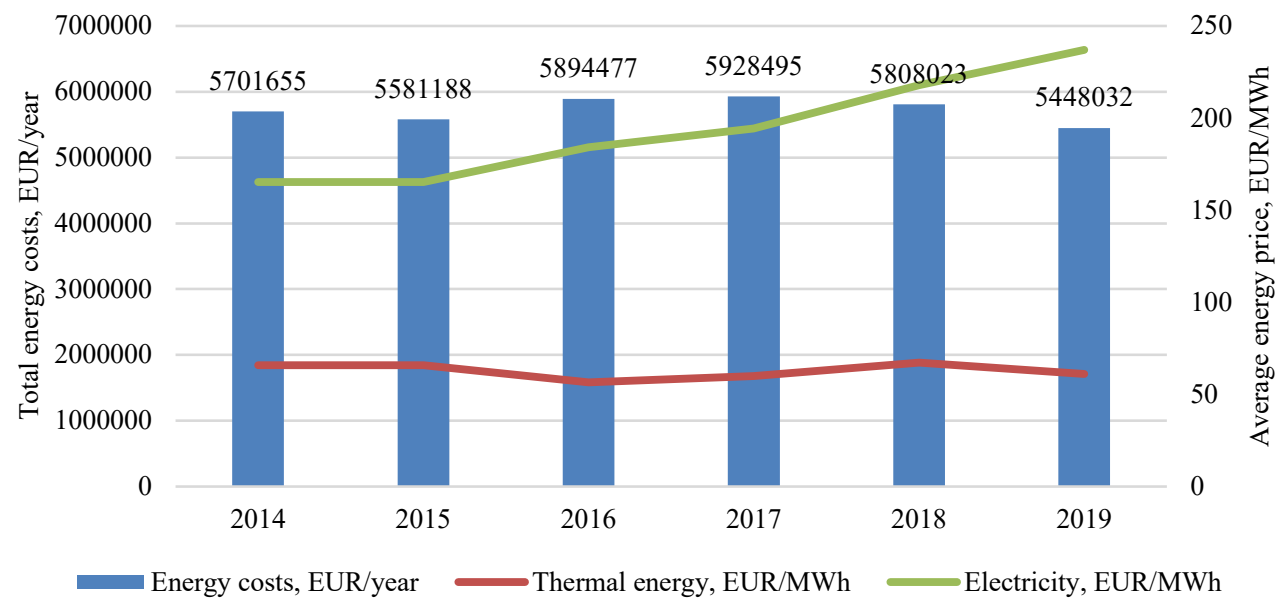

Fig. 11. Energy costs in 123 municipal buildings in the city of Daugavpils.

According to the information received from the Daugavpils energy manager, implementation of EnMS and certification of the system has cost approximately 12 thousand euros. Investments paid off in less than one year.

\section{DisCuSSION}

Previous research has shown that in many cases municipalities are encouraged to develop sustainable energy and climate action plans, but eventually they do not know how to properly work with data and make evidence-based decisions. In contrary, the city of Daugavpils has not only developed SECAP but has also created a system for data collection and analysis, and continues to improve and extend the system. A few strategic decisions have allowed them to move forward with sustainable development.

Daugavpils chose to use EnMS as a tool for addressing energy issues, as the municipality has very diverse needs. In this case application of BEMS approach could become too heavy and knowledge intensive for such a large system of more than 100 buildings. Success of Daugavpils' case could be explained by transparency and adaptability of the system, allowing for its gradual expansion and improvement. 
The first research question was - what is the precondition for implementation of EnMS? In case of Daugavpils, the most significant factors were two, one was that the administration of the municipality acknowledged that energy efficiency measures do not reach the expected results. The other factor was legislative requirements that came into force shortly before the municipality implemented EnMS.

The second research question concerned the benefits of implementation of EnMS. In case of Daugavpils, success can be defined first of all by energy and financial savings. In the meantime, the system has also ensured a structure and knowledge to municipality for future decisions. From the very beginning, Daugavpils included within the system most of the city's infrastructure from three main sectors - public lighting, public transport and municipal buildings. They successfully certified the system according to LVS EN ISO 50001:2012, and are gradually adding more objects to the system. Daugavpils has managed to reduce heat energy consumption by $12 \%$ compared to 2016 in the building sector. Most importantly, the municipality has started to use data for decision making. According to SECAP one of the targets for 2020 was to reduce heat energy consumption in public buildings by $10 \%$, comparing to 2014 , and this target has been achieved already in 2019 reaching a $11 \%$ reduction (comparing 2016 to 2019, reduction is $12 \%$ ). Real data for public lighting and transport have also been collected. As the historical data were based on many theoretical assumptions, and real data were not available, detailed analyses of these two sectors are not included in this article. For these two sectors, the main goal was to start collecting real data to understand the actual situation and to enable future decision making based on this data.

The third research question was - what the most important factors for EnMS are to successfully function. In the case of Daugavpils, one of the most important success factors, was the appointment of an energy manager, and very specific allocation of responsibilities among employees. Most importantly, the distribution of responsibilities was done by official order of the executive director, giving a signal from municipal leaders that there is support for EnMS in the city council.

Even though EnMS implementation in Daugavpils can be considered as successful, heating data analysis show that not always the largest and most inefficient buildings are chosen for renovation, even though data is available and acknowledged. A significant factor in the decision-making process is the availability of financial support from different funds and programmes. Therefore, in recent years renovation projects were implemented mostly in educational buildings.

Since previous research about the application of ISO 50001 in municipalities is limited, this research paper gives significant insight on the effectiveness of using an energy management system approach in municipalities. Further research should be done, to find how EnMS could be implemented in smaller municipalities or more rural municipalities, and how street lighting and public and municipal transport data could be analysed.

\section{REFERENCES}

[1] Vatn A. Markets in environmental governance. From theory to practice. Ecological Economics 2015:117(1):225-233. https://doi.org/10.1016/j.ecolecon.2014.07.017

[2] Verbruggen A., Laes E., Woerdman E. Anatomy of Emissions Trading Systems: What is the EU ETS? Environmental Science and Policy 2019:98(May):11-19. https://doi.org/10.1016/j.envsci.2019.05.001

[3] Salim H. K., et al. Global trends in environmental management system and ISO14001 research. Journal of Cleaner Production 2018:170:645-653. https://doi.org/10.1016/j.jclepro.2017.09.017 
[4] De Oliveira J. A., et al. Environmental Management System ISO 14001 factors for promoting the adoption of Cleaner Production practices. Journal of Cleaner Production 2016:133:1384-1394.

https://doi.org/10.1016/j.jclepro.2016.06.013

[5] Mazzi A., Toniolo S., et al. The combination of an Environmental Management System and Life Cycle Assessment at the territorial level. Environmental Impact Assessment Review 2017:63:59-71. https://doi.org/10.1016/j.eiar.2016.11.004

[6] ISO. The ISO 50001:2011 standard. Geneva, 2011.

[7] McKane A., et al. Thinking Globally: How ISO 50001 - Energy Management can make industrial energy efficiency standard practice. Technical Report 2009:65-76. https://doi.org/10.2172/983191

[8] Backlund S., et al. Extending the energy efficiency gap. Energy Policy 2012:51:392-396. https://doi.org/10.1016/j.enpol.2012.08.042

[9] Backlund S., et al. Energy efficiency potentials and energy management practices in Swedish firms. ECEEE 2012 Summer Study On Energy Efficiency in Industry 2012:669-677.

[10] Pelser W. A., Vosloo J. C., Mathews M. J. Results and prospects of applying an ISO 50001 based reporting system on a cement plant. Journal of Cleaner Production 2018:198:642-653. https://doi.org/10.1016/j.jclepro.2018.07.071

[11] McKane A., et al. Predicting the quantifiable impacts of ISO 50001 on climate change mitigation. Energy Policy 2017:107(May):278-288. https://doi.org/10.1016/j.enpol.2017.04.049

[12] Böttcher C., Müller M. Insights on the impact of energy management systems on carbon and corporate performance. An empirical analysis with data from German automotive suppliers. Journal of Cleaner Production 2016:137:1449 1457. https://doi.org/10.1016/j.jclepro.2014.06.013

[13] Phan T. N., Baird K. The comprehensiveness of environmental management systems: The influence of institutional pressures and the impact on environmental performance. Journal of Environmental Management 2015:160:45-56. https://doi.org/10.1016/j.jenvman.2015.06.006

[14] Ferrón Vílchez V. The dark side of ISO 14001: The symbolic environmental behavior. European Research on Management and Business Economics 2017:23(1):33-39. https://doi.org/10.1016/j.iedeen.2016.09.002

[15] Arimura T. H., Darnall N., Ganguli R., Katayama H. The effect of ISO 14001 on environmental performance: Resolving equivocal findings. Journal of Environmental Management 2016:166:556-566. https://doi.org/10.1016/i.jenvman.2015.10.032

[16] Laskurain I., Heras-Saizarbitoria I., Casadesús M. Fostering renewable energy sources by standards for environmental and energy management. Renewable and Sustainable Energy Reviews 2015:50:1148-1156. https://doi.org/10.1016/j.rser.2015.05.050

[17] ISO. The ISO Survey of certifications to management system standards. 2017.

[18] Sousa Lira J. M., Salgado E. G., Beijo L. A. Which factors does the diffusion of ISO 50001 in different regions of the world is influenced? Journal of Cleaner Production 2019:226:759-767. https://doi.org/10.1016/j.jclepro.2019.04.127

[19] Yuan J., Farnham C., Emura K. Development and application of a simple BEMS to measure energy consumption of buildings. Energy and Buildings 2015:109:1-11. https://doi.org/10.1016/j.enbuild.2015.10.012

[20] Papantoniou S., Kolokotsa D., Kalaitzakis K. Building optimization and control algorithms implemented in existing BEMS using a web based energy management and control system. Energy and Buildings 2015:98:45-55. https://doi.org/10.1016/j.enbuild.2014.10.083

[21] Jones S. R., et al. A control methodology for Building Energy Management Systems (BEMS) in heat networks with distributed generation. Energy Procedia 2018:153:295-302. https://doi.org/10.1016/j.egypro.2018.10.011

[22] Rocha P., Siddiqui A., Stadler M. Improving energy efficiency via smart building energy management systems: A comparison with policy measures. Energy and Buildings 2015:88:203-213. https://doi.org/10.1016/j.enbuild.2014.11.077

[23] Seeam A., Laurenson D., Usmani A. Evaluating the potential of simulation assisted energy management systems: A case for electrical heating optimisation. Energy and Buildings 2018:174:579-586. https://doi.org/10.1016/i.enbuild.2018.06.063

[24] Dzene I., Polikarpova I., Zogla L., Rosa M. Application of ISO 50001 for Implementation of Sustainable Energy Action Plans. Energy Procedia 2015:72:111-118. https://doi.org/10.1016/j.egypro.2015.06.016

[25] Beihmanis K., Rosa M. Energy Management System Implementation in Latvian Municipalities: From Theory to Practice. Energy Procedia 2016:95:66-70. https://doi.org/10.1016/j.egypro.2016.09.018

[26] Kamenders A., Rosa M., Kass K. Low carbon municipalities. The impact of energy management on climate mitigation at local scale. Energy Procedia 2017:128:172-178. https://doi.org/10.1016/j.egypro.2017.09.038.

[27] Aboltins R., Blumberga D. Key Factors for Successful Implementation of Energy Efficiency Policy Instruments: A Theoretical Study and the Case of Latvia. Environmental and Climate Technologies 2019:23(2):187-206. https://doi.org/10.2478/rtuect-2019-0063

[28] Kona A., et al. Covenant of Mayors: Greenhouse Gas Emissions Achievements and Projections. Joint Research Centre Science Hub. Luxembourg: Publications Office of the European Union, 2016. https://doi.org/10.2790/11008

[29] Covenant of Mayors. Covenant of Mayors Annual report. Luxembourg: Publications Office of the European Union, 2018. 
[30] Petersen J. P. The application of municipal renewable energy policies at community level in Denmark: A taxonomy of implementation challenges. Sustainable Cities and Society 2018:38:205-218. https://doi.org/10.1016/j.scs.2017.12.029

[31] Suharevska K., Blumberga D. Progress in Renewable Energy Technologies: Innovation Potential in Latvia. Environmental and Climate Technologies 2019:23(2):47-63. https://doi.org/10.2478/rtuect-2019-0054

[32] Feofilovs M., Pakere I., Romagnoli F. Life Cycle Assessment of Different Low-Temperature District Heating Development Scenarios: A Case Study of Municipality in Latvia. Environmental and Climate Technologies 2019:23(2):272-290. https://doi.org/10.2478/rtuect-2019-0068

[33] Polikarpova I., Lauka D., Blumberga D., Vigants E. Multi-Criteria Analysis to Select Renewable Energy Solution for District Heating System. Environmental and Climate Technologies 2019:23(3):101-109. https://doi.org/10.2478/rtuect-2019-0082

[34] Central Statistical Bureau of Latvia. Number of population in cities and counties. 2019

[35] Daugavpils municipality. Sustainable energy and climate action plan of Daugavpils city 2016-2020. pp. 2-82, 2016. (in Latvian)

[36] Jekabsone A., Kamenders A., Rosa M., Kaselofsky J., Schule R. Assessment of the Implementation of Sustainable Energy Action Plans at Local Level. Case Study of Latvia. Environmental and Climate Technologies 2019:23(2):3646. https://doi.org/10.2478/rtuect-2019-0053

[37] Cabinet regulation No. 348. Republic of Latvia Cabinet regulation No. 348. Adopted 25th June 2013. "Methodology for Calculating the Energy Performance of a Building”, 2013.

[38] Cabinet regulation No. 432. Republic of Latvia Cabinet regulation No. 432. Adopted 17th September 2019. "LBN 003-19 "Construction Climatology", 2019.

[39] European Parlament and the Council. European directive 2012/27/EU OF THE EUROPEAN PARLIAMENT AND OF THE COUNCIL of 25 October 2012 on energy efficiency, amending Directives 2009/125/EC and 2010/30/EU and repealing Directives 2004/8/EC and 2006/32/EC. Official Journal of the European Union 2012:L315/1.

[40] The Clean Energy Ministerial. Global Energy Management System Implementation. Case Study - City of Daugavpils. 2017. (in Latvian)

[41] Daugavpils municipality. Handbook "Development and implementation of Energy management system according to ISO 50001:2012”. Ekodoma, 2016. (in Latvian)

[42] Bonacina F., et al. Industrial energy management systems in Italy: State of the art and perspective. Energy Procedia 2015:82:562-569. https://doi.org/10.1016/j.egypro.2015.11.871

[43] Thollander P., Ottosson M. Energy management practices in Swedish energy-intensive industries. Journal of Cleaner Production 2010:18(12):1125-1133. https://doi.org/10.1016/j.jclepro.2010.04.011 